\title{
Hélène Millot, Choréographies manifestaires
}

\section{Sandra Garbarino}

\section{(2) OpenEdition}

\section{Journals}

\section{Édition électronique}

URL : https://journals.openedition.org/studifrancesi/41068

DOI : 10.4000/studifrancesi.41068

ISSN : 2427-5856

\section{Éditeur}

Rosenberg \& Sellier

\section{Édition imprimée}

Date de publication : 1 juillet 2004

Pagination : 217

ISSN : 0039-2944

\section{Référence électronique}

Sandra Garbarino, « Hélène Millot, Choréographies manifestaires », Studi Francesi [En ligne], 142 (XLVIII I

I) | 2004, mis en ligne le 30 novembre 2015, consulté le 09 septembre 2021. URL : http://

journals.openedition.org/studifrancesi/41068; DOI : https://doi.org/10.4000/studifrancesi.41068

\section{Ce document a été généré automatiquement le 9 septembre 2021.}

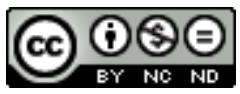

Studi Francesi è distribuita con Licenza Creative Commons Attribuzione - Non commerciale - Non opere derivate 4.0 Internazionale. 


\title{
Hélène Millot, Choréographies manifestaires
}

\author{
Sandra Garbarino
}

\section{RÉFÉRENCE}

HÉLÈnE MILLOT, Choréographies manifestaires, in A.A.V.V., Spectacles de la parole, a cura di Hélène Millot e Corinne Saminadayar-Perrin, Édition des Cahiers Intempestifs, 2003, («Lieux littéraires»), pp. 361-374.

1 Selon H. Millot, la scène littéraire des années 1885-1918 est caractérisée par la prolifération de groupes, revues et manifestes littéraires. Au moment où le maître-mot paraît être individualisme, le spectacle de la parole devient collectif, se transforme en scène. Ainsi, l'A. de l'article analyse le champ littéraire comme scène en parvenant à affirmer que « la littérature ne peut exister publiquement que si elle sait se mettre en scène, ou en d'autres termes que si elle sait se faire manifeste ". C'est pour que la littérature démontre son existence que naissent donc les manifestes. Descendants des préfaces, ces documents se réfèrent à des modèles dont les principaux paraitraient la harangue militaire, la vaticination messianique et le tract électoral. La conclusion de l'article vise à démontrer que cette spectacularisation de la parole se radicalise avec les mouvements futuriste et dada qui permettent au manifeste de devenir un «objet poétique à part entière». 